\title{
Refugees right to work: the characteristics of Brazilian migration policies from the end of World War II to 2019
}

\author{
Andreia de Fátima HoElzle Martins ${ }^{12}$ \\ WeSCley Silva XAVIER ${ }^{2}$ \\ ${ }^{1}$ Universidade do Estado de Minas Gerais, Belo Horizonte - MG, Brazil \\ ${ }^{2}$ UNIVERSIDAdE FEDERAL DE VIÇOSA, VIÇOSA - MG, BRAZIL
}

\begin{abstract}
This article aims to understand the characteristics of migration policies targeted at refugees, especially concerning the right to work, from the end of World War II to 2019. Migration policy can be defined as the rights and obligations of migrants, including the guarantees and regulations immigrants have when residing in a foreign country. Labor shortages, national security, international treaties, and humanitarian issues are often recurring concerns in migration policy management. This study relied on scientific, journalistic and institutional (legislative) sources available in digital media. Documentary data analysis focusing on themes regarding migration policy, refugees, and refugee employment were used. As a result, it has been concluded that Brazil had inherited conservative, nationalist, and racist policies in the scope of migration. Furthermore, regardless of the progress made during the democratic period, there is still room for improvement in refugee assistance following its legalization in the country. The right to work and the documentation required to work legally are safeguarded to immigrants recognized as refugees. It also includes groups who have acquired the right to validate their qualifications. Nonetheless, the policy has failed to ensure access to employment and protect these groups from performing illegal work without labor rights, which, in turn, highlights the need for public policies that may intervene in this regard. In conclusion, we show the relevance of migration policies to the legal recognition of refugees' rights, especially concerning their right to work.
\end{abstract}

Keywords: Brazilian Migration policy. Right to work. Refugees.

\section{O direito ao trabalho para refugiados: características das políticas migratórias brasileiras do pós-guerra até 2019}

\section{Resumo}

O artigo tem como objetivo compreender as características das políticas migratórias para refugiados, especificamente em relação ao direito ao trabalho, desde a segunda-guerra até 2019. Políticas migratórias podem ser definidas como direitos e deveres dos imigrantes, incluindo garantias e regulamentações relacionadas à residência e entrada em um país estrangeiro. Escassez de mão de obra, segurança nacional, tratados internacionais e questões humanitárias são algumas das questões frequentes que influenciam a gestão de políticas migratórias. Para tanto, foi realizada uma pesquisa documental e bibliográfica, no qual utilizou-se de fontes científicas, jornalísticas e institucionais (legislações), disponíveis em mídia digital e que tratavam de temas como política migratória, refugiados e direito ao trabalho de refugiados. Como resultado, conclui-se que o Brasil herdou políticas nacionalistas, conservadoras e racistas no escopo da política de migração. Além disso, apesar de ter tido avanços significativos durante o período democrático, ainda há espaço para melhorias na assistência aos refugiados após sua legalização no país. O direito ao trabalho e a documentação necessária para trabalhar legalmente são salvaguardados para os imigrantes reconhecidos como refugiados, incluindo o direito de validar seus diplomas, estudos e qualificações. No entanto, a política falhou em garantir o acesso ao emprego e proteger esses grupos de realizar trabalhos ilegais, o que, por sua vez, ressalta a necessidade de políticas públicas que possam intervir nesse sentido. Por fim, destacamos a relevância das políticas de migração para o reconhecimento legal dos direitos dos refugiados, especialmente no que tange ao seu direito ao trabalho.

Palavras-chave: Políticas migratórias brasileiras. Refugiados. Direito ao trabalho.

\section{El derecho al trabajo de los refugiados: características de las políticas migratorias brasileñas desde la posguerra hasta 2019}

\section{Resumen}

Las políticas de migración pueden definirse como los derechos y deberes de los inmigrantes, incluidas las garantías y regulaciones relacionadas con la residencia y el ingreso a un país extranjero. La escasez de mano de obra, seguridad nacional, tratados internacionales y cuestiones humanitarias son algunos de los temas que influyen en la gestión de las políticas de migración. Con este fin, se llevó a cabo una investigación documental y bibliográfica, utilizando fuentes científicas, periodísticas e institucionales, disponibles en medios digitales y que trataban temas como política de inmigración, refugiados y derecho al trabajo de los refugiados. Como resultado, se concluye que Brasil heredó políticas nacionalistas, conservadoras y racistas en el ámbito de la política de migración. Además, a pesar de haber logrado un progreso significativo durante el período democrático, todavía hay margen para mejorar la asistencia a los refugiados después de su legalización en el país. El derecho al trabajo y la documentación necesaria para trabajar legalmente están salvaguardados para los inmigrantes reconocidos como refugiados, incluido el derecho a validar sus diplomas, estudios y calificaciones. Sin embargo, la política no ha garantizado el acceso al empleo ni protege a estos grupos de realizar trabajos ilegales, lo que, a su vez, subraya la necesidad de políticas públicas que puedan intervenir en este sentido. Finalmente, destacamos la relevancia de las políticas de migración para el reconocimiento legal de los derechos de los refugiados, especialmente con respecto a su derecho al trabajo.

Palabras clave: Políticas migratorias brasileñas. Refugiados. Derecho al trabajo. 


\section{INTRODUCTION}

In 2015, during an interview for the Brazilian magazine Galileu, the Polish philosopher Zygmunt Bauman was asked about a solution to the problems arising from migration. He replied that migration is an ancient phenomenon, which goes back to the dawn of history. What is different now, he pointed out, is the fact that government officials regard their cultures as superior to the immigrants' (Bernardo, 2015).

At another level, the changes described by Bauman have not been restricted to government officials or policymakers but have also been disseminated among citizens who see 'their spaces' cohabited by individuals coming from various places and backgrounds. The risk of cultural hybridism and the competition for jobs seem like threats, which was observed in the Brexit campaign in the UK.

In particular, the demarcations (not just geographic, but social, economic, ethnic and cultural) between the countries in the global north and the global south have produced a large number of migrants, who, having their economic ambitions and/or basic rights denied, have fled their homelands searching for new opportunities. This has reinforced the link between the geography of movements and the reconfiguration of the world economy (Castles, 2004).

Crises or forced migrations are inserted in this context and are caused by conflicts, natural disasters and/or severe economic restrictions in a given country or region (Calegari, 2018), originating from the collapse of States without the legal apparatus to protect vulnerable people, which are called stateless territories (Bauman, 2017). The nature of these flows is what gives rise to the migratory modality known as refugee.

Although there is no legal or scientific consensus as to what a refugee is, this study adopts the definition established by the United Nations High Commissioner for Refugees (UNHCR), which classifies them as people whose lives are threatened, among other things, by "massive violation of human rights". According to UNHCR (2019), 70 million people worldwide fled their homes in 2018. Among them, 22.5 million were refugees and more than half were aged 18 or less.

The definition of the refugee has changed over the years. The Refugee Convention, drawn up in 1951 to manage the migratory crisis generated by World War II, classifies as refugees all those who had to leave their homes for fear of persecution due to events before 1951 (UNHCR, 2020). Although the Convention text was ratified in 1966, taking away the condition of the events before 1951 (UNHCR, 2020), the document that currently presents the definition adopted by the UNHCR is the Cartagena Declaration, formulated in 1984 by South American government representatives, presenting the discussion between refuge and human rights violations (Barreto \& Leão, 2010).

Although this discussion is complex among migration scholars, given the many categories in this process, it should be noted that the difference between a refugee immigrant and other immigrants is mainly that the former has been forced to migrate due to the violation of basic rights, usually caused by war and/or persecution (UNHCR, 2020). Even so, we highlight that no migration is totally voluntary, but influenced by economic, political, ideological, cultural elements, among others (Castles, 2004).

Although Bauman's assertion about the conflicting nature of migration has the notion of cultural superiority endorsed by government officials as its turning point, immigrant integration to a new country can only become less dramatic through government policies. More specifically, government actions are designed and implemented through migration policies, which can be defined as the rights and obligations of migrants and include the guarantees and public policies regarding the entry, stay or resettlement of immigrants into a given country (Hammar, 2005). Furthermore, such initiatives concern national and international interests and encompass political, economic, social, historical and ideological issues (Loescher, 1996).

In the case of migration policies for refugees, the vulnerability of these groups has to be considered, for they require even more instruments and mechanisms to facilitate their integration. Studies have highlighted the significance of labor to foster the refugee integration process and acknowledged employment opportunities as a centerpiece of immigration. Indeed, refugees themselves often emphasize this aspect when asked about their permanence and integration into the asylum country (Ager \& Strang, 2008; Fleay, Hartley \& Kenny, 2013; Tomlinson \& Egan, 2002). 
In addition, Tomlinson and Egan (2002) have pointed out that employment concerns not only the economic sphere but also the social and psychological aspects of subjects. These include the development of linguistic competence, the expansion of social networks, and the strengthening of self-esteem and self-confidence. Fostering legal employment opportunities also keeps immigrants away from labor analogous to slavery, which is a very likely outcome caused by the refugees' lack of language competence, inability to vouch for their professional experience, and the scarce knowledge about the local community (Onraet, Van Hiel, Valcke \& Van Assche, 2019).

The intensification of refugee flow, when compared to economic migration, affects the very reconfiguration of the geography of migratory movements. The new context of forced migration has made the South-South migration a significant possibility, giving relevance to broader migration laws and policies, especially those that ensure the right to work and expand employment opportunities. As pointed out by UNHCR (2019), nine out of ten refugees found asylum in countries in the Global South or intermediaries.

Among the Latin American countries, Brazil has been a historic destination for immigrants and is marked by an intense migratory flow of refugees. As a result of World War II, critical laws and policies began to be incorporated by the local government for the reception and integration of this migration group. Moreira (2012) draws attention to the mostly regulatory nature of these policies, which need to set out instruments to facilitate integration, including the assurance of the right to work.

Acknowledging the advancement of these policies and understanding their historical and political context allows potential improvements to be pointed out. In other words, identifying positive achievements is paramount to strengthen the debate on migration policies. In this sense, this article aims to understand the characteristics of migration policies for refugees, especially concerning the right to work, from the end of World War II to 2019. To this end, we adopted bibliographic and documentary research to collect scientific sources, documents, and newspaper articles dealing with migration policies in the established period.

The next section addresses the theoretical framework of migration policies and the importance of labor to integrate refugees. In the following section, we highlight the methodology adopted in this study. The results present a retrospective of Brazilian migration policy from the end of World War II to 2019, focusing on aspects related to the right to work. The last section discusses the results and reflects on the future of Brazilian refugee policies.

\section{The right to work and its significance for refugee integration}

Migration policy is defined herein as the regulation of the rights and obligations of migrants and includes the guarantees and public policies regarding the entry, stay or resettlement of immigrants into the asylum country (Hammar, 2005). Labor shortage, national security, compliance with international treaties, and attention to humanitarian issues are recurring concerns in the scope of migration policy management (Salomon, 1991). More specifically regarding refugee policy, Moreira (2012) argues that it is mainly related to political issues, although there is no consolidated literature dealing with the topic.

In the field of migration studies, migrant integration has been a recurring theme, encompassing different approaches (Siciliano, 2013). Castles (2003) argues that integration is a complex concept that demands contextualization and has no universal definition. According to the author, there is no single theory or model addressing immigrant and refugee integration. Therefore, each author tends to focus on distinct aspects according to the objects of study and the migration context in question.

When theorizing about immigration policy, Hammar (2005) argued that it should be approached beyond the parameters of immigration control (regulation policy) as immigrant integration should be addressed as well. Regulation policies include the control of migratory flows, the criteria used to regularize immigrants, and the legal procedures to grant visas or citizenship to immigrants. Regarding migrant integration, Ager and Strang (2008) highlighted several relevant variables for an effective immigrant policy, specifically targeted at refugees. The authors classify integration factors anything from basic legal aspects to aspects that facilitate permanence, such as knowledge of the language, social connections and access to health, education and housing policies. According to Crisp (2004), refugees need access to these rights even more, as they go through a range of traumatic experiences before and during the migration process, such as the sensation of insecurity (possibly provoked by persecution or war from the home country), loss of family members and friends and violence caused 
by criminal groups, mainly in relation to women, children and the LGBTQI+ population, as are often stigmatized by the society granting asylum.

Refugees are characterized as a different population group when compared to immigrants as they demand specific integration policies (Vroome \& Tubergem, 2010). Moreover, they live in constant fear of the strange environment as well as being considered strange in the eyes of others (Bauman, 2009). Besides the vulnerabilities of this group, their arrival in the new country usually happens with previous knowledge of the new environment and without the documents necessary for work, health, housing, and services. In order to reduce this gap, the right to work and access to employment opportunities have been mentioned as crucial dimensions in the integration process of these groups (Ager \& Strang, 2008; Fleay et al., 2013). Indeed, the right to work is established by the World Conference on Human Rights, which dictates that

Every individual has the right to be able to work, allowing him/her to live in dignity. The right to work contributes at the same time to the survival of the individual and to that of his/ her family, and insofar as work is freely chosen or accepted, to his/her development and recognition within the community (Fleay et al., 2013, p. 5).

However, these rights are interpreted and implemented differently in each country, depending on their government, history, social and economic structure, among other factors that shape the immigrant and refugee regulation policy. When studying the importance of work for refugees living in Australia, Fleay et al. (2013) highlighted the relevance of this component to the other economic, social, and psychological aspects involved. Other authors, such as Simões (2017), state that aspects such as employment opportunities tend to be the most emphasized variable by the refugees themselves because the lack of such opportunities often jeopardizes their permanence in the asylum country.

Likewise, when theorizing about the aspects that constitute a successful (or ideal) integration process for refugees, Ager and Strang (2008) ranked access to employment as a key variable for migrant integration. The authors identified these aspects through the perception of refugees and workers involved in welcoming these individuals into their new countries (Ager \& Strang, 2008).

Employment opportunities have been associated with the promotion of independence, the expansion of social networks, and the opportunity to develop linguistic competence. Furthermore, they are a crucial factor in the development of self-esteem and self-confidence (Tomlinson \& Egan, 2002). In this sense, employment is a factor that goes beyond the acquisition of material goods or mere survival; it can also interfere with the social and psychological aspects.

The key point is that refugee labor conditions are a central aspect for adapting to a new country, as refugees face various difficulties concerning the recognition and validation of their degrees, qualifications and work experiences (Ager \& Strang, 2008). In addition to these, there is yet another barrier that prevents refugees from being perceived as qualified professionals. Those have been highlighted by Vroome and Tubergen (2010), for whom the employment opportunities available to refugees are linked to other aspects such as local language fluency, the establishment of networks in the communities where they live, and proof of previous work experience.

The results of the study show that there is a statistically relevant relation between job hiring and linguistic proficiency; in such a way that better-paying jobs are occupied by refugees that speak the local language (Vroome \& Tubergen, 2010). This correlation may be explained by the better work quality of those who know the language, as this is a demand for the best job positions (Chiswick \& Miller, 2001).

Little (1994) stresses that refugee stigma can also hinder the integration and provision of basic needs. This happens because the policies usually targeted at those groups are based on welfare, hence they do not provide refugees with self-reliance conditions. Furthermore, the refugee label can be associated with a form of threat in societies that perceive those individuals as fugitives or criminals. In this sense, as advocated by Hammar (2005), it is necessary to go beyond regulation policies that merely safeguard access to work, by promoting other policies that can ensure decent work opportunities. These, in turn, prevent vulnerable refugees from performing labor analogous to slavery. 


\section{METHODOLOGY}

To achieve the proposed objective, we conducted a retrospective of refugee migration policies covering the period between the end of World War II and 2019. Data collection and analysis were based on documentary and bibliographic research. Documentary data collection is a research type that limits its database to documents that have not received any type of scientific treatment, such as reports, books, magazines, news stories, among others (Oliveira, 2007).

Sá-Silva, Almeida and Guindani (2009) point out the complexity of defining what a document is while acknowledging that it can be anything that serves as a source or historical record of past or recent events. The authors emphasize that documentary analysis requires the understanding of the contexts in which documents were produced, as well as their veracity. In this sense, in addition to other documents such as reports, we have adopted bibliographic research for further understanding the contexts in question. According to Oliveira (2007), bibliographic research relies on documentary sources that have already received previous attention, in other words, secondary sources that can ground the discussion of a given topic. Therefore, the documentary sources in this study were public archives (particularly the legal framework on the topic) and news articles and stories. In turn, the bibliographic sources were academic papers, theses, and dissertations.

We have established a timeline covering the period between 1945 and 2019, containing the most significant milestones regarding refugees and the right to work. The main data source for documentary research was the Brazilian Chamber of Deputies archive, where 147 statutory texts were accessed by searching the term "refugee" under the "legislation" category. The purpose of the query was to identify the provisions for refugee policies, focusing on fragments that dealt with the right to work, policies aimed at expanding job opportunities, and labor rights regarding this specific category of migration. We also paid attention to the definition of refugee adopted by the legislation, as it determines who will be granted access to the rights provided for by the law.

We also relied on journalistic sources, which are essentially available as digital media. Newspaper articles were used to address the most recent period (2017-2019), during which few scientific papers were published, due to the temporal location of such events. Journalistic sources with high legitimacy were prioritized, bringing only news stories published in newspaper websites ${ }^{1}$ to the study. Publications by UNHCR and CONARE ("National Committee for Refugees") were also queried.

Moreover, since this study focused on the Brazilian context, we relied on scientific sources available in three databases, namely Scielo, Periódicos Capes, and Capes' Banco de Teses e Dissertações. We relied on scientific data to elucidate the context of migration policies and understand their associated milestones. All searches were performed using the queries "migration policy" and "refugee", which should appear in the title or abstract of the scientific documents in question. Whenever the advanced search was unfeasible by the title or abstract, the documents were read by human readers to identify the selected keywords.

Documentary analysis was carried out from a historical framework, so as to organize the data according to the characteristics of the migration policies of each period and relating them to the (political, economic, social) context in which they were produced. The data were analyzed in three stages, characterized by bibliographical and documental analyses. The first was organized by year and with documents related to legislation, highlighting changes in decrees and laws about refugees and their right to work.

Next, data from bibliographical sources were analyzed. The selected articles were grouped according to significance to migrant and refugee policy. The third stage chronologically paired documental and bibliographical data, analyzing migration policy for refugees, and their right to work.

Brazilian refugee policy: the relationship between refugees and labor in the period between the end of World War II and 2019

The choice to deal with refugee migrant policies in the period that followed the end of World War II is justified by the number of individuals who became refugees during and after the war. More specifically, it was also motivated by the high number of immigrants in the refugee category who were granted asylum in Brazil. This was also when the Refugee Status Act was agreed internationally, as a result of the UN Convention Relating to the Status of Refugees in 1951, which went into effect in 1967 (UNHCR, 2019).

\footnotetext{
${ }^{1}$ We adopted the idea of traditional and hegemonic media as trustable newspaper website. For instance, O Globo, Folha de São Paulo, Estadão, El Pais Brasil, Le Monde Diplomatique, BBC Brasil and others.
} 
However, before introducing the post-war context, we must point out that, from a historical perspective, a sizeable portion of the Brazilian population has consisted of immigrants. It was only in 1930, as part of President Getúlio Vargas' nationalist project, that the country "closed its doors" to immigration by adopting a quota system (Andrade, 2013). Taking advantage of the accomplishments of previous years, a period of reopening began in 1945, during which a racist and utilitarian bias was added to migration policies. As a result, only Europeans, anti-communists, and workers who were able to work in the fields were welcome (Andrade, 2013; Moreira, 2012).

Concurrent with the end of World War II, Brazil was going through an industrialization process that was part of a broader nationalist project characteristic of the previous period (the so-called "Estado Novo"). It was in this context that in 1945, Decree-Law No. 7,967 (1945) was enacted, laying the foundation for Brazilian migration policy. Its main goal was to regulate the Brazilian migratory flow, which had been characterized by the intense adhesion of war refugees, and to reconcile such flow with the national interests. Considering the definitions outlined by the decree concerning the profile of the desired immigrants, we have come to realize that it only includes individuals who were able to contribute to the country's economic activities, as described in Articles 2 and 57 of the decree-law.

Article 57. The Federal Government should promote, through the Brazilian Institute of Geography and Statistics, in collaboration with the competent body, the creation and systematization of official placement services in all municipalities, so as to examine and meet labor needs through internal immigration and the introduction of foreign workers.

Chapter I - Article 2. The admission of immigrants shall consider the need to preserve and develop, in the ethnic composition of the population, the most convenient characteristics of their European ancestry, as well as the protection of Brazilian workers (Decreto-Lei no 7.967, 1945).

It should be noted that Decree-Law No. 1967 (1945) does not adopt the term refugee at all. This can be explained by the incipience of the debate on this type of immigration classification in Brazil, which only became relevant to the Brazilian government later. In 1946, under the administration of General Gaspar Dutra, the government took part in the debates on migration and became a member of the International Rescue Committee (IRC). Although only the immigration policy established after 1946 is specifically targeted at refugees, it is characterized by the same restrictions provided for by the Decree-Law 1.967 (1945).

Furthermore, that legal text provided only regulation policies (Hammar, 2005), as well as the immigrant profile desirable for the country's interests. Moreira (2012) attributes the decision to grant asylum to post-war refugees to the economic, ethnic and demographic interests of the time, in a period during which sectors such as industry and agriculture had to be strengthened. More specifically, welcoming Soviet refugees contributed to delegitimizing the Soviet Union as the nation that would lead the world's development, and helped accomplish Brazil's foreign policy objectives, which were inclined towards the United States.

The author also points out that such policy was extremely selective (a factor that exposes its ethnic purposes), as it exclusively recognized European applicants as refugees. This policy can be interpreted as a legacy of the Getúlio Vargas administration, mainly as a result of Estado Novo, which aimed to whiten the Brazilian population and form groups that corroborated the nationalist cultural ideal (Andrade, 2013).

In this sense, the migration policy initiated by Eurico Gaspar Dutra praised the entry of immigrants, including refugees, as long as they met certain criteria, which Salles (2007) referred to as "agricultural" and "industrial", demonstrating the economic component that influenced that policy. Even so, Brazil was one of the key Latin American destinations for war refugees and exiles, and the period between 1946 and 1948 was paramount for the enactment of decrees that guaranteed fundamental rights to those groups.

The Mixed Commission for the Brazil-Intergovernmental Committee on Refugees was set up during this period, to discuss actions granting asylum to such individuals (Silva, 2013). In turn, in 1948, the Brazilian government and the Preparatory Commission for the International Refugee Organization signed an administrative agreement, based on Decree-Law No. 25,796 (1948), which defined refugees as the individuals who fulfilled the conditions provided in paragraph 2 of article 1, transcribed as follows:

A person who, as a result of events occurring before January 1, 1951, fears being persecuted for reasons of race, religion, nationality, social group or political opinion, or has left their country of origin and who cannot or, due to this fear, does not wish to rely on the protection offered by that country; or who has no nationality and has left the country where they have resided as a result of such events, cannot or, due to the aforementioned fear, does not wish to return to it (Decreto № 25.796, 1948). 
The Decree-Law 25,796 (1948) shows us that the same treatment offered to other foreigners would also be assured to refugees regarding labor rights. It includes the guarantee of salary and social security, provided that the conditions for reinstating the immigrant's employment are observed (Decreto no 25.796, 1948). This, in turn, is in line with what Hammar (2005) defined as immigrant policy. The decree was an important milestone to assure the right to work to refugees in Brazil, although it was limited to European refugees affected by the events occurring before January 1, 1951.

In this sense, although the decree introduced a very narrow definition of refugee, it acknowledged the importance of labor for refugee integration, by guaranteeing the right to work, a dimension that has been emphasized by Fleay, Hartley and Kenny (2013). Even so, the scope of the legal text was limited to allowing refugees to perform formal work, without however designing instruments to facilitate access to employment opportunities.

The restriction on the definition of a refugee was reaffirmed in Decree No. 50.215 (1961), which promulgated the Convention Relating to the Status of Refugees, held in Geneva on July 28, 1951. Although Brazil was the first South American country to ratify the convention, the established definition of a refugee was not fully applied in the decree. Furthermore, article 17 was removed, which assured refugees the same professional rights as an employee born in the country. Finally, it stated that in the event of restrictive measures designed to protect the national worker, these would not include individuals bearing refugee status (Decreto no 50.215, 1961).

Important aspects outlined by the decree address the right to family reunion and education, which are also relevant to the full integration of the refugee. Once again, it ensures compliance with relevant initiatives for the integration of asylum seekers into the new country, while recognizing aspects that are not only instrumental but also psychological (by allowing family reunion, for instance). When elaborating on the dimensions of an ideal integration, Ager and Strang (2008) drew attention to the importance of meeting demands whose factors imply psychological issues, such as the right to free religion and to the family reunion.

Although Brazil played a significant role in sheltering post-war refugees, the borders were closed for the sake of national security during the military regime. Foreigners came to be perceived as a threat to natives, and the decision to receive immigrants became a matter of national sovereignty. Although the treatment offered to refugee migrants differed from foreigners in general, some decrees led to setbacks with regard to labor rights. Indeed, the legal framework kept vetoes regarding equal treatment of refugees and Brazilian citizens and excluded the right to unemployment benefits for refugees with legal status (Decreto-Lei no 406, 1968).

Again, it is necessary to retrieve the close relationship to which Bauman calls our attention, addressed in the introductory section of this paper. The legal aspects, depending on those who are governing the country, directly impact the integration capacity of these individuals, since they acquire different rights, especially regarding labor rights. However, these are not limited to the legal framework, as their intersection with the social sphere makes these very individuals undesirable, reinforcing the negative stigma previously highlighted by Crisp (2004).

It is worth noting that no rules provided the regularization of non-European refugees in the country during that period. Although UNHCR recognized Chileans and Argentines as refugees (who were also fleeing military regimes), Brazilian law did not recognize them as such. Considering that they were also political exiles, the Brazilian government had no interest in regularizing their status in the country (Moreira, 2012). However, also during the military regime, the Decree No. 70,946, of August 7, 1972, changed the definition of refugee, which came to encompass only persecuted individuals, regardless of the period that had been previously determined by Decree-Law 25,796/1948, before January 1, 1951 (i.e., before World War II), (Decreto no 70.946, 1972).

The 1980s marked a period of the reestablishment of refugees' rights. In 1987, Resolution No. 17 was outlined. It included "temporary foreigners", who had not been formarly classified as refugees and were also victims of political persecution by dictatorial regimes (Silva, 2013). With the end of the military regime and the promulgation of the 1988 Constitution, Brazil needed to attain legitimacy in the international arena as a democratic country. Therefore, as previously stated, the government triggered a new process to open borders and acceptance of immigrants and refugees began (Moreira, 2012).

As part of the democratic transition, the Decree No. 99,757, dated December 3, 1990, gave new wording to Decree No. 50,215, of January 28, 1961. Responsible for promulgating the Convention Relating to the Status of Refugees, it determined "that the Convention Relating to the Status of Refugees will be executed and complied with in its entirety" (Decreto no 99.757, 1990). 
Therefore, it guaranteed equal rights for local citizens and refugees, concerning salary and wages, by including the article 17 of the Refugee Status Act, which had been excluded by previous decrees.

Another important milestone for refugees in the scope of the right to work was the possibility of requesting the Work and Social Security Card (CTPS) when the refugee status had been granted.

In 1991, the inter-ministerial ordinance no. 394 established by the Executive Branch provided that "[...] when an individual is granted refugee status in Brazil, he/she shall be granted a temporary visa that should be communicated to the Ministry of Justice for due publication in the Federal Official Journal (DOU). Therefore, the refugee whose status is published is authorized to apply for his Alien Identity Card (CIE) with the Federal Police. This document allowed the legal stay and the subsequent issuance of the Work and Social Security Card (CTPS) (Silva, 2013, p. 140).

With the possibility of issuing work and social security cards for refugees as soon as they were recognized as such, the Brazilian legislation came to provide instruments to make employment opportunities feasible. This, in turn, de-characterized a strictly regulatory policy (Hammar, 2005).

This period was also marked by the arrival of Angolans (black immigrants) (CONARE, 2017), which represented a significant break from the idea of promoting immigration for racial whitening purposes. During the administrations of Itamar Franco and Fernando Henrique Cardoso, the organization Caritas Internationalis was invited to contribute to the debate, so as to improve migration policies for refugees. The participation of this kind of organization in the debate was characterized as an important measure for the country's democratic transition and a means to tackle initiatives that could compromise human rights. The National Human Rights Program, together with the debate on refugees, gave rise to Law 9,474/1997, which was extremely significant for defining mechanisms that led to the implementation of the 1951 Refugee Statute Act (Lei no 9.474, 1997).

Law No. 9,474 (1997) was characterized by being the first mandatory normative instrument concerning refugees in Brazil, as well as the first law to establish implementation mechanisms and address the enforcement of rights. In addition, it should be noted that it broadened the definition of a refugee:

Article 1. An individual shall be recognized as a refugee if:

I- due to well-founded fears of persecution for reasons of race, religion, nationality, social group or political opinions, he or she is out of his or her country of nationality and cannot or does not wish to rely on the protection of such country;

II - having no nationality and being out of the country where he or she had previously retained permanent residence, cannot or does not wish to return to such country based on circumstances mentioned in item I above;

III - due to severe and generalized violation of human rights, he or she is compelled to leave his or her country of nationality to seek refuge in a different country.

Among the important initiatives for the implementation of the Refugee Status Act, the creation of the National Committee for Refugees (CONARE) stands out. It is responsible for outlining and coordinating the actions necessary for effective protection, assistance, and legal support to refugees and it has members of non-governmental organizations on its board. Legal advances give refugees the right to obtain an identity document (to prove their legal status) and a social security and work card. Another important aspect was provided by article 4 of chapter II, regarding local integration. It established facilitated conditions for the recognition of degrees and certificates (Lei no 9.474, 1997), modifying employment access conditions for such groups. These changes had a significant impact, given their potential to mitigate the difficulty in recognizing and validating the qualifications of refugee immigrants, an aspect previously pointed out by Ager and Strang (2008).

According to a document published by CONARE (2017), the number of recognized refugees grew substantially after the law was implemented. Before its enactment, Brazil had 1,746 refugees, and in 2014, after the creation of CONARE and Law No. 9.474 (1997), the total reached 5,892. Currently, the number of recognized refugees reaches 11,231 (CONARE, 2019). However, in legal terms, that number drops to approximately 7,000 , due to events such as death, acquisition of Brazilian nationality, or changes in migration status. 
The transformations brought about by the $21^{\text {st }}$ century, particularly the intensification of production and circulation of goods on a global scale, added to the growing tensions caused by historical conflicts and the activities of terrorist groups. These, in turn, have brought migration to the forefront once again. In addition to broader media coverage, the number of individuals seeking asylum has increased, bringing along the need to design new migration policies.

Concomitantly, broad debates on human rights compose the scenario. In 2003, Legislative Decree No. 231 became the first norm to address human trafficking and other forms of exploitation. The relevance of that decree is explained because it combats "sexual exploitation, forced labor or services, slavery or labor analogous to slavery" involving foreigners (Decreto legislativo no 231, 2003). Since that decree has become a protective element for vulnerable individuals (Hammar, 2005), it demonstrates how a legal aspect contributes to protecting refugees from slave labor or other forms of exploitation. Furthermore, it enabled recovery initiatives for individuals living in such conditions, including "Medical, psychological and material assistance and employment, education, and training opportunities" (Decreto legislativo no 231, 2003).

We must emphasize that these initiatives are planned together with non-governmental organizations, which join as partners. Several legislative texts referring to refugees provide for the participation of such organizations. As a consequence, they generally assume a vital role in integrating these individuals and in enforcing the rights provided by law (Calegari, 2018).

After the 1997 law, along with the new migratory demands of the $21^{\text {st }}$ century, Brazil began to accept refugees from different parts of the world, mostly from the African continent, which accounted for 63\% of the total until 2012 (Calegari, 2018). In 2018, most refugees (approximately 30\%) were of Syrian origin, due to the massive flight of citizens amid the Syrian civil war. This context shifted away from the policy of granting asylum for racial whitening. Instead, it was associated with the enforcement of refugees' human rights (Calegari, 2018).

With the increase in asylum requests due to the natural disasters in Haiti, the aforementioned Syrian civil war, among other demands, new regulations that safeguarded the right of entrance into the national territory were put in place. Asylum seekers who were typically victims of serious threats to human rights such as the Haitians and Syrians had their access and stay legalized in the country (Calegari, 2018).

In the case of Syrians, Normative Resolution No. 17 (2013) was enacted (Resolução Normativa no 17, 2013). The resolution, scheduled to be revoked in 2015, was extended until 2017. It issued that immigrants enjoying refugee status would have their foreign degree validation facilitated, due to the impossibility of retrieving documents during the war. This measure can also be characterized as another instrument to expand employment opportunities, in addition to simply regulating it. Even so, Moreira (2012) and Calegari (2018) highlight that Brazilian migration policy is more concerned with regulatory aspects, lacking mechanisms that may help to enforce the rights provided by law.

Although it was under scrutiny for a while, the most recent change was the new migration act passed in May 2017 (Law No. 13,445, of May 24, 2017). Containing 20 vetoes, it was promulgated by then-President Michel Temer and became the mandatory instrument regulating immigrant status in Brazil. Although it is considered an advance for Brazilian migration policies (despite the vetoes), the policy suffered internal pressure with fascist and xenophobic undertones (Assis, 2018). Among the advances made possible by the new law, Assis (2018) highlights the right to apply for social welfare programs such as "Bolsa Família" and "Minha Casa Minha Vida", as long as the minimum income requirements of the applicant are met.

Despite the improvements, there is criticism regarding the veto on the expansion of the definition of a refugee. As an example, it is worth mentioning that it does not recognize as refugees the "applicants for humanitarian visas, victims of human trafficking, victims of slave labor, migrants serving time or who are free pending trial, and unaccompanied minors" (Lei no 13.445, 2017). The argument for the veto was that the "mechanism presents impropriety, by unduly listing individuals who are free pending trial as members of a vulnerable group and therefore subject to immigration policy benefits" (Lei no 13.445, 2017).

Hence, the veto prevents refugee policy from including other vulnerable groups. Also, failure to grant refugee status for humanitarian visa applicants means that these individuals cannot enjoy the rights assigned to the category. This raises the issue of receiving Venezuelan asylees who currently hold humanitarian visas (Assis, 2018).

In the following year, Decree No. 9.277, of February 5, 2018, provided emergency assistance measures to receive people in vulnerable situations due to the migratory flow caused by a humanitarian crisis. Article 4 addresses these measures as follows: 
"I - social protection; II - health care; III - provision of educational activities; IV - training and professional qualification". Indeed, these specifically impact access to employment opportunities by Venezuelan immigrants. This decree represents an important advancement, as it facilitates the integration process of Venezuelan immigrants even before their recognition as refugees, being fundamentally relevant in cases of a humanitarian crisis.

On one hand, 2018 advanced the legal framework of policies targeted at refugees (in particular the Venezuelans). On the other hand, it was also characterized by the hardening of military action against those who crossed the border and occupied the city streets, especially in northern Brazil. From a legal standpoint, the enactment of Decree No. 9.501, of September 11, 2018, stands out. Indeed, article 1 authorized the use of the Armed Forces "for the Guarantee of Law and Order, from August 29 to October 30, 2018" in some areas of the state of Roraima. This decision culminated not only in violent actions perpetrated by police forces but also instilled the already heated reaction of the Brazilian residents towards the Venezuelans.

In this context, the UN organized the Global Compact for Migration. The agreement was motivated by the current global migration crisis in which 3.4\% of the global population are refugees. According to the UN, up to 2018, 3,323 people had died or disappeared on migratory routes, which made it a global matter (ONU News, 2018). Although Brazil adopted the compact in 2018, during the Temer administration, the election of Jair Bolsonaro's has jeopardized the granting of asylum to new refugees. Indeed, Brazil has since refused to adopt the UN Global Pact on Migration (Globo, 2018).

Another initiative marked the setback of refugee policies in Brazil. A declaratory act revoked the Provisional Measure No. 860, of December 3, 2018, which authorized "the donation of financial resources to the United Nations High Commissioner for Refugees, and to the International Organization for Migration for purposes of welcoming people in situations of vulnerability resulting from the migratory flow caused by a humanitarian crisis" (Ato declaratório do presidente da mesa no 28, 2019). In this sense, the trends point to less tolerant policies towards refugees and immigrants living in vulnerable conditions in the near future.

\section{FINAL CONSIDERATIONS}

This article aimed to identify the characteristics of migration policies for refugees, especially those pertaining to the right to work, from the end of World War II to 2019. Through bibliographic and documentary research, we gathered scientific sources, documents, and newspaper articles on migration policies in the established period. We concluded that migration policies obey ideological and political interests that change with governments and historical contexts. It is noteworthy to say that the first stage of migration policies in Brazil, during the Getúlio Vargas administration, stood out for its conservative, nationalist and racist character (as it was aimed at the whitening of the Brazilian population), marked by exclusionary migration policies that only allowed European refugees into the country (that is, white immigrants).

However, over the years, the definition of refugee and the rights associated with their working conditions in Brazil has been continuously expanded. Except setbacks during the military dictatorship, when certain labor rights for immigrants were excluded, we can state that labor-related rights have advanced in general. The Constitution of 1988, which marks Brazilian redemocratization, and the Law of 2017 are important milestones in migration policy, especially for refugees. The consituiton guarantees the right to work and identity cards for all refugees and breaks from the racist aspect of pre-1988 migration policy by embracing non-white refugees.

In addition to safeguarding remuneration and access to social security, incremention came with policies that provided for the validation of foreign degrees and the establishment of partnerships with non-governmental organizations. As a result, employment opportunities were made available to immigrants and refugee workers received treatment equivalent to local workers.

This improvement is relevant since refugees were benefited not only with the right to work. They have also been able to enjoy employment and labor rights essential for their integration, which, in turn, have safeguarded their basic living 
conditions. We can notice that, as early as 1948, the right to work was already provided for, as well as a set of labor rights for refugees. However, substantial change came from the definition of a refugee. Previously limited to Europeans coming to Brazil in the post-war period, it has now been extended to all who have been persecuted due to their ethnicity, and political, religious and/or sexual orientation, as well as those who suffered a violation of their human rights, or have been forced to flee their countries.

It is important to highlight that decrees are constantly used as a normative instrument for individuals living as refugees. However, only after the democratic transition of Brazil, have laws specifically targeted at this group been enacted. This is relevant because decrees have no force of law and may or may not be effectively enforced, whereas laws and acts must be complied with.

The Law of 2017 is a milestone because it is considered one of the most advanced in Latin American, and despite not expanding the definition of refugee, it guarantees access to housing and basic income policies. Even though these issues are not strictly related to work, they are important points to integration policy that go beyond regulatory means.

We also concluded that the Brazilian immigration policy treats immigrants and refugees unequally. Indeed, it is less restrictive towards individuals who fall under the latter classification. For this reason, the country holds an eminent position in the scope of migration legislation. However, regulation alone cannot guarantee its effectiveness and the resulting refugee integration. Its paramount importance is to allow access to employment opportunities, Portuguese learning, validation of foreign degrees and studies, training, and other instruments and mechanisms that may facilitate the insertion of refugees into the local labor market. Such policies are essential not only to safeguard the right to decent work but also to reduce the vulnerability of refugees to criminals such as drug and human traffickers, terrorists, and individuals who subject refugees to labor analogous to slavery.

We understand that the key achievements are still recent and need further consolidation if Brazil is to fulfill its humanitarian role in the face of the global migration crisis. This is true especially in because of the threats arising from conservatism and nationalism, which can generate significant setbacks for the achievements of the democratic period, corroborating once again the idea that all non-mandatory policies are under threat by conservative governments.

\section{ACKNOWLEDGEMENTS}

We would like to acknowledge CAPES for the financial support to this research. 


\section{REFERENCES}

Ager, A., \& Strang, A. (2008). Understanding Integration: a conceptual framework. Journal of Refugee Studies, 21(2), 166-191.

Alto Comissariado das Nações Unidas para os Refugiados. (2019). Dados sobre Refúgio. Retrieved from http://www.acnur.org/ portugues/dados-sobre-refugio/

Alto Comissariado das Nações Unidas para os Refugiados. (2020). Convenção de 1951. Retrieved from https://www.acnur.org/ portugues/convencao-de-1951/

Andrade, G. (2013). A trajetória da extrema-direita no Brasil: integralismo, neonazismo e revisionismo histórico (1930-2012). In Anais do 5o Simpósio Internacional Lutas Sociais na América Latina "Revoluções nas Américas: Passado, Presente e Futuro", Londrina, PR.

Assis, G. (2018). A nova lei de migração no Brasil: Avanços e Desafios. In R. Baeninger, L. M. Bógus, J. B. Moreira, L. R. Vedovato, D. M. Fernandes, M. R. Souza, ... L. F. A. Magalhães. (Orgs.), Migrações Sul-Sul (pp. 609-623). Campinas, SP: Nepo/Unicamp.

Ato declaratório do presidente da mesa № 28, de 15 de maio de 2019. (2019). Brasília, DF: Diário da União.

Barreto, L., \& Leão, R. (2010, julho). O Brasil e o espírito da declaração de Cartagena. Forced Migration Review, 35, 1-5.

Bauman, Z. (2009). Confiança e Medo na Cidade. Rio de Janeiro, RJ: Editora Zahar.

Bauman, Z. (2017). Estranhos à Nossa Porta. Rio de Janeiro, RJ: Editora Zahar.

BBC News. (2019, janeiro 08). BBC News: em comunicado a diplomatas, governo Bolsonaro confirma saída de pacto de migração da ONU. G1. Retrieved from https://g1.globo.com/politica/noticia/2019/01/08/ em-comunicado-a-diplomatas-governo-bolsonaro-confirma-saidade-pacto-de-migracao-da-onu.ghtml

Bernardo, A. (2015, novembro 19). Zygmunt Bauman fala sobre migração e relacionamentos. Galileu. Retrieved from https:// revistagalileu.globo.com/Revista/noticia/2015/11/solido-comouma-pedra-aos-90-anos-zygmunt-bauman-fala-sobre-migracao-erelacionamentos.html

Calegari, M. (2018). Condições de vida dos refugiados sírios em São Paulo. In R. Baeninger, L. M. Bógus, J. B. Moreira, L. R. Vedovato, D. M. Fernandes, M. R. Souza, ... L. F. A. Magalhães. (Orgs.), Migrações Sul-Sul (pp. 325-228). Campinas, SP: Nepo/Unicamp.

Castles, S. (2004). Why migration policies fail. Ethnic and racial studies, 27(2), 205-227.

Chiswick, B., \& Miller, P. (2001). A Model of Destination-Language Acquisition: Application to Male Immigrants in Canada. Demography, 38, 391-409.

Conselho Nacional de Refugiados. (2017). Refúgio em Números. Retrieved from http://www.acnur.org/portugues/wp-content/ uploads/2018/01/refugio-em-numeros-2010-2016.pdf

Conselho Nacional de Refugiados. (2019). Refúgio em números. Retrieved from https://www.justica.gov.br/seus-direitos/refugio/ refugio-em-numeros
Crisp, J. (2004). The local integration and local settlement of refugees: a conceptual and historical analysis. Geneva, Switzerland: UNHCR, Evaluation and Policy Analysis Unit.

Decreto Legislativo № 231, de 29 de maio de 2003. (2003). Submete à consideração do Congresso Nacional o texto da Convenção das Nações Unidas contra o Crime Organizado Transnacional e seus dois Protocolos, relativos ao Combate ao Tráfico de Migrantes por Via Terrestre, Marítima e Aérea e à Prevenção, Repressão e Punição do Tráfico de Pessoas, em Especial Mulheres e Crianças, celebrados em Palermo, em 15 de dezembro de 2000. Brasília, DF: Senado Federal. Retrieved from http://legis.senado.leg.br/norma/538684/ publicacao/15829041

Decreto № 25.796, de 10 de novembro de 1948. (1948). Manda executar o Acôrdo Administrativo entre o Brasil e a Concessão Preparatória da Organização Internacional e Refugiados, firmado no Rio de Janeiro, a 30 de abril de 1948. Brasília, DF: Presidência da República. Retrieved from http://www.planalto.gov.br/ccivil_03/ Atos/decretos/1948/D25796.html

Decreto № 50.215, de 28 de janeiro de 1961. (1961). Promulga a Convenção relativa ao Estatuto dos Refugiados, concluída em Genebra, em 28 de julho de 1951. Brasília, DF: Presidência da República. Retrieved from http://www.planalto.gov.br/ccivil_03/ decreto/1950-1969/D50215.htm

Decreto № 70.946, de 7 de agosto de 1972. (1972). Promulga o Protocolo sobre o Estatuto dos Refugiados. Brasília, DF: Presidência da República. Retrieved from https://www.planalto.gov.br/ccivil_03/ decreto/1970-1979/d70946.htm

Decreto № 99.757, de 29 de novembro de 1990. (1990). Retifica o Decreto $n^{\circ} 98.602$, de 19 de dezembro de 1989 , que deu nova redação ao Decreto $n^{\circ} 50.215$, de 28 de janeiro de 1961, que promulgou a Convenção relativa ao Estatuto dos Refugiados. Brasília, DF: Presidência da República. Retrieved from http://www.planalto.gov.br/ccivil_03/ decreto/1990-1994/D99757.htm

Decreto-Lei № 406, de 31 de dezembro de 1968. (1968). Estabelece normas gerais de direito financeiro, aplicáveis aos impostos sôbre operações relativas à circulação de mercadorias e sôbre serviços de qualquer natureza, e dá outras providências. Brasília, DF: Presidência da República.

Decreto-Lei № 7.967 de 18 de setembro de 1945. (1945). Dispõe sôbre a Imigração e Colonização, e dá outras providências. Brasília, DF: Presidência da República. Retrieved from http://www.planalto. gov.br/ccivil_03/decreto-lei/1937-1946/del7967.htm

Fleay, C., Hartley, L., \& Kenny, M. (2013). Refugees and asylum seekers living in the Australian community: The importance of work rights and employment support. Australian Journal of Social Issues, 48(4), 473-493.

Hammar, T. (2005). European immigration policy: A comparative study. Cambridge, UK: Cambridge University Press.

Lei № 9.474, de 22 de julho de 1997. (1997). Define mecanismos para a implementação do Estatuto dos Refugiados de 1951, e determina outras providências. Brasília, DF: Presidência da República. Retrieved from http://www.planalto.gov.br/ccivil_03/leis/19474.htm 
Lei № 13.445, de 24 de maio de 2017. (2017). Brasília, DF: Presidência da República. Retrieved from http://www.planalto.gov.br/ccivil_03/_ Ato2015-2018/2017/Lei/L13445.htm

Little, P. (1994). Espaço, memória e migração. Por uma teoria de reterritorialização. Textos de História. Revista do Programa de Pósgraduação em História da UnB, 2(4), 5-25.

Loescher, G. (1996). Beyond charity: International cooperation and the global refugee crisis: A twentieth century fund book. Oxford, UK: Oxford University Press.

Moreira, J. (2012). Política em relação aos refugiados no Brasil (19472010) (Doctoral Dissertation). Universidade Estadual de Campinas, Campinas, SP.

Oliveira, M. M. (2007). Como fazer pesquisa qualitativa. Petrópolis, RJ: Vozes.

Onraet, E., Van Hiel, A., Valcke, B., \& Van Assche, J. (2019). Reactions towards Asylum Seekers in the Netherlands: Associations with Rightwing Ideological Attitudes, Threat and Perceptions of Asylum Seekers as Legitimate and Economic. Journal of Refugee Studies, 103, 1-18.

ONU News. (2018, dezembro 08). Pacto global de migração, entenda mais. Retrieved from https://news.un.org/pt/story/2018/12/1650601

Resolução normativa № 17 de 20 de setembro de 2013. (2013). Dispõe sobre a concessão de visto apropriado, em conformidade com a Lei no 6.815, de 19 de agosto de 1980, e do Decreto 86.715, de 10 de dezembro de 1981, a indivíduos forçosamente deslocados por conta do conflito armado na República Árabe Síria. Brasília, DF: Diário Oficial da União.
Resolução normativa № 25 de 14 de setembro de 2017. (2017). Prorroga a vigência da Resolução Normativa no 17 , de 20 de setembro de 2015. Brasília, DF: Diário Oficial da União.

Salles, T. (2007). A política Imigratória Brasileira no Pós-Segunda Guerra Mundial e os Refugiados: Uma leitura da revista de imigração e colonização. Cena Internacional, 9(2), 184-210.

Salomon, K. (1991). Refugees in the cold war: toward a new international refugee regime in the early postwar era. Lund, Sweden: Lund University Press.

Sá-Silva, J. R., Almeida, C. D., \& Guindani, J. F. (2009). Pesquisa documental: pistas teóricas e metodológicas. Revista Brasileira de História \& Ciências Sociais, 1(1), 1-15.

Siciliano, A. L. (2013). A política migratória brasileira: limites e desafios (Masther Thesis). Universidade de São Paulo, São Paulo, SP.

Silva, C. (2013). A política brasileira para refugiados (1998-2012) (Doctoral Dissertation). Universidade Federal do Rio Grande do Sul, Porto Alegre, RS.

Simões, G. (2017). Venezuelanos em Roraima: características e perfis da migração venezuelana para o Brasil. In J. Woischnik (Ed.), Fluxos migratórios e refugiados na atualidade. Rio de Janeiro, RJ: Fundação Konrad Adenauer Stiftung.

Tomlinson, F., \& Egan, S. (2002). From marginalization to (dis) empowerment: organizing training and employment services for refugees. Human Relations, 55(8), 1019-1043.

Vroome, T., \& Tubergen, F. (2010). The employment experience of refugees in the Netherlands. International Migration Review, 44(2), 376-403.

Andreia de Fátima Hoelzle Martins

ORCID: https://orcid.org/0000-0003-4773-5074

Master in Management from Federal University of Viçosa; Lecturer at Minas Gerais State University. E-mail: hmartins.andreia@gmail.com

Wescley Silva Xavier

ORCID: https://orcid.org/0000-0003-3524-3566

Ph.D. in Management from Federal University of Minas Gerais; Associate Professor at Federal University of Viçosa. E-mail: wescley@ufv.br 